\title{
A Defense of the Excellence of Bradamante
}

The merits and shortcomings of Bradamante's conduct in the Orlando furioso have long been a subject of controversy among critics of the poem. Some have found the heroine to be perfection itself, a woman who "assomma le qualità piú elette della donna cinquecentesca; l'ardore verecondo di Gaspara Stampa e di Barbara Torella; la tristezza di Vittoria Colonna; l'accortezza di Isabella Gonzaga; l'audacia ardimentosa di Caterina Sforza. ${ }^{\prime 1}$ Others have found her a disappointing figure who does not live up to the reader's expectations for the behavior of a lady knight. Long ago Pio Rajna complained, "mi piace poco . . . quando verso la fine del poema me la vedo diventare una buona figliuola qualunque, che non ha il coraggio di disubbidire alla mamma." ${ }^{2}$ More recently, Bradamante has been rejected in favor of Marfisa because Marfisa is "a credible person, positive, clear-headed, well-integrated," whereas Bradamante, required "to relinquish the role of guerriera and accept that of passive donna," is "basically unsure which role she wishes to play. ${ }^{3}$ Different as these evaluations of Bradamante are, they share one common factor: all of them are based on assumptions about independent women current in modern times; none is founded on a real knowledge of sixteenthcentury attitudes. As a result each may explain the attraction or repulsion his day feels for Bradamante, but none can accurately assess the literary failures or successes of the character since none is aware of the qualities of the contemporary ideal against which she must be measured.

It is surprising that both the presentation of the Renaissance ideal of womanhood in the Furioso and Bradamante's relation to it have gone unanalyzed in this period of interest in independent women, but critics interested in the poem's discussion of women have generally turned their attention to the more colorful issues of female infidelity and the double standard rather than to the topic of woman's ability and right to act in traditional male roles. Even the two best studies of the use of the Renaissance controversy 
about women in the poem neglect this topic. Mario Santoro's exciting study of Rinaldo's attitude toward women, "Rinaldo ebbe il consenso universale," is limited to the issues Rinaldo raises, all of them sexual in nature, ${ }^{4}$ and Robert Durling's excellent analysis of the narrator's attitude toward women devotes only a one paragraph summary to the narrator's eulogies of famous women at XX.i-iii and XXXVII.i-XXv. ${ }^{5}$ As a result of the lack of interest in the topic of women's moral, mental, and physical abilities, many important aspects of the Bradamante-Ruggiero plot have remained unexplored or inadequately understood. To remedy this problem I will briefly present the major Renaissance theories about women's abilities and social responsibilities and then, in the light of these theories, I will evaluate the poem's attitude toward women as expressed through the character of Bradamante. The result will be, I hope, a clarification of the characterization of one of the heroines of the Furioso and a revelation of the major part the sixteenth-century discussion about women's proper social role plays in the poem.

\section{I}

During the Renaissance ideas about women changed substantially. From the time of Petrarch through the end of the sixteenth century a great number of books were written asserting the excellence of women and a lively debate was carried on among literary figures about the relative merits of the sexes. This debate was at once serious, concerned with a real re-evaluation of woman and her social rights, and rhetorical, concerned with finding clever ways to bottle a standard group of arguments for and against women.

The discussion of women was not new to the European tradition, of course; satiric literature mocking women and claiming they were dominated by every possible vice was very popular in the Middle Ages and throughout the Renaissance, but until the Renaissance serious thought about women was mainly in a religious context. Women were assumed to be inferior to men in moral, spiritual, and physical capacity and the rare admirable woman was praised for transcending the natural capacity of her sex. The established opinion about women was based on the scholastic interpretation of a certain number of Biblical and Aristotilian texts. Aquinas' analysis of such questions as "whether women should have been made in the first production of things" (yes) and "whether Adam's sin was more grievous than Eve's?" (no) gave authority to the belief that women are defective crea- 
tions "subject to man because in man the discretion of reason pre-

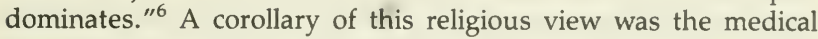
opinion: that women were ruled by their passions. Together these ideas suggested that women needed male guidance in their private life as well as in social and political life.

Some of the earliest challenges to the assumption of the natural inferiority of women in all fields were put forward by secular writers in Florence and in Northern Italian centers of learning in the fifteenth century. Renaissance humanists found new ideas about women in classical sources and reinterpreted the standard Biblical and medical texts to come to conclusions which allowed a greater dignity to women. The good woman was no longer seen as an exception to her sex but as a realization of its natural potential.

One of the most important subjects of study for the humanists was the family, especially its dual function as essential economic unit and instructor in morals. The greatest Renaissance theorist on the family, Leon Battista Alberti, and other important figures of the period, like Giovanni Pontano, Francesco Barbaro, and San Bernardino of Siena, all advise that domestic affairs be put entirely in charge of the wife, whom they find to be naturally clever at household economy. They see her role as budgeter and safeguarder of what her husband brings in as of comparable importance with the husband's role as provider. Although they do assign the husband the role of final authority and expect that the wife will obey him, they believe that husbands should love their wives, and they reject the old method of disciplining a wife by beating her and replace it with gentle reasoning. They are convinced that women are both intelligent and capable of moral behavior, and they argue that a mother's influence over her children is beneficent. They assign her the role of moral and religious educator of her children, a role that is now traditional but was new at that time. ${ }^{8}$ The ideas of these writers on the family may seem reactionary to us today, but they were innovative and even controversial in their own day because they accorded respect to women for moral sense and gave critical social importance to their domestic function.

At the same time that the idealization of woman's domestic role was beginning, humanists interested in education turned their attention to the topic of the education of women. They devised programs of study for the daughters of the rich, women who, in the years before marriage, had leisure from daily responsibilities in the home. Vittorino da Feltre, Guarino, and Leonardo Bruni, the greatest educators of the times, discarded the old belief that learning was inappropriate to women and advocated more knowledge 
for women than had before been considered either useful or prudent. In a seminal work on the education of girls, the "De Studiis et Litteris," Bruni sees the field of religion and morals as one to which women are particularly adapted, but he believes them clever enough to extract the moral value from pagan works as well as Christian. ${ }^{9}$ Educators did not teach girls in this way in order to revolutionize the role they played in life; even the daughters of the powerful were destined, for the most part, to be wives and mothers. ${ }^{10}$ Although they wanted women to gain distinction by their studies, humanist educators advocated education for women primarily because they believed this learning would develop their innate morality and improve their performance of their domestic duties.

Some women, of course, because of rank or determination were freed from living entirely within the limits of the home. These women were highly respected, and the fame of many Renaissance queens, noblewomen, and female poets has endured to our day because of the praise given them in their own time. One of the most popular vehicles for the commendation of women was a genre invented by Boccaccio, the collection of biographies of famous women. Some of these collections emphasize domestic accomplishments and appreciate learning in women only for the contribution it makes to their practice of religion, ${ }^{11}$ others praise the graceful balance of learning, artistic endeavor, or political acumen with domestic concerns.

A major example of this genre is Sabadino degli Arienti's Gynevera de le clare donne, a collection of biographies of queens, lady warriors, scholars and wives offered to Gynevera Sforza di Bentivogli. The biographies Sabadino presents are seldom in harmony with the known facts about the women he praises; Gynevera di Bentivogli was a vicious woman, yet the author describes her as selfless in her exercise of power. This disjunction between the real women and Sabadino's account of them diminishes the value of his collection for a historian seeking accurate biographic information, but it makes the work all the more valuable for the history of ideas. Sabadino is aware of a contemporary ideal and he reshapes even the most unsuitable character to fit it.

Sabadino's biographies of lady warriors are especially interesting for the study of Bradamante. The military ladies are of two kinds. On the one hand are Joan of Arc and Maria Pozzuoli, women like Marfisa who are uninterested in marriage; Sabadino presents these women as admirable but odd. The other group is made up of women who are not professional women-at-arms: like Bradamante, they are or will be wives, and they act in the interest 
of their husbands or families. If her sons are minors or her husband absent, a woman of this type is the equal of the best man, but when her husband returns or the sons reach maturity, she resumes her secondary role. Caterina Visconte inspired the people of Milan to fight to keep the city independent for the sake of her two sons; Theodora di Rodali bought friends for her husband during his exile and encouraged him to revenge an insult and seize power on his return; Isabella of Naples led troops to secure her lands, yet felt she should not rule alone and asked her nobles to elect a co-regent for her while her husband was prisoner. According to Sabadino all the members of the last group also demonstrated sixteenth-century female interests in morality and piety. They founded monasteries and churches, endowed poor young ladies with dowries, and were chaste. Even the most independent ruler in the collection, Mathilda Comitissa, is described as wearing the "candido manto de pudicicia et religione"12 and is portrayed as acting in unison with her husband until he died. She was not brought up to rule, and she did not seek power, but once it was hers she used it well.

These sixteenth-century collections of biographies differ significantly from Boccaccio's De Mulieribus Claris in their attitude toward accomplished women. He is uneasy with women who demonstrate the virtues of courage, strength, and heroism and treats them as exceptions to the frail nature of their sex; he frequently suggests that such women have male souls in female bodies. ${ }^{13}$ The later books of famous women are attempts to dispel this belief in the inevitable inferiority of all women. They assert that women's actions arise out of native virtue, not out of a near miraculous infusion of male spirit.

The worth of women is argued most extremely in another group of works that first appeared in the Renaissance, the treatise on the excellence of women. Works of this type adduce arguments proving women's equality or even superiority to men on moral, intellectual, and physical grounds. Examples of this very popular form are Galeazzo Flavio Capella's Della eccellenza et dignità delle donne (Rome, 1525), the anonymous Defensione delle donne, and Book III of Castiglione's Cortegiano. ${ }^{14}$ These books catered to the taste of a Northern Italian court audience proud of its unusual women who were educated and whose life at court made them active, though unofficial, figures in the political life of their time. Along with presenting organized refutations to the standard arguments of the misogynists, the authors of these books postulate a Golden Age of sexual equality when women held equal political power with men; they assert that we are igno- 
rant of the importance of women in history because male writers have deliberately omitted the roles women have played; and they argue that women have a more strongly rooted sense of sexual morality than men.

The former greatness of women is argued quite ingeniously but without an ability to conceive of women actually sustaining an equal role. This is seen in ludicrously inconsistent historical recreations. In his Della eccellenza et dignità delle donne, Galeazzo Flavio Capella, a Milanese humanist courtier, imagines that women once were judges along with men, but, as the language used in court got less and less polite, the male judges removed the female judges to protect their sensibilities. He also cites the Amazons as proof that women chose to be great warriors when it served a good purpose but that now they have judged war a base activity and do not participate. ${ }^{15}$ In his La nobiltà delle donne Lodovico Domenichi suggests that the most ancient writers wrote praise of men rather than of women because praising women was too easy and they wanted to set themselves a difficult topic. The ancient Greeks interpreted this lack of praise as proof of women's inferiority, and there the tradition began. ${ }^{16}$ These myths of origins may sound comic to modern ears, but they are not satire against women; they are attempts to grapple with a serious problem: how women came to hold an inferior position in society if they were created equal.

Pro-feminist writers are more successful at proving the natural sexual morality of women because they refer to their male reader's own experience of women instead of fabricating historical evidence. How many women, they say, have you attempted to seduce and failed to win? Which one of you has not at least attempted infidelity ${ }^{17}$ They assert that the double-standard serves men because it allows them to indulge themselves without criticism. ${ }^{18}$ Capella explains that the contemporary adultery laws which are very severe to women and indulgent to men exist because women are capable of fidelity whereas there is no hope of controlling men. ${ }^{19}$ The result of all these arguments is not a change in the behavior required of women. All these writers see chastity as an important female virtue, and none of them advocate that women give in to their lascivious inclinations. By proving that women are naturally better restrained than men, these pro-feminists bind women more tightly than ever into the traditional expectations of chastity.

These treatises on women made three important contributions to Renaissance thought. First, they codified a set of arguments in favor of women that countered the traditional arguments against 
them. Second, they made it impossible to assume the naturalness of traditional assumptions about women's empty-headedness or untrustworthiness. Third, they created a new ideal of womanhood: the woman who emerges from these books is clever, educated, pretty, modest, chaste, able to handle herself in company without desiring to dominate, and able to rule should the occasion arise.

Modern as these books may sound in their assertion of sexual equality, they differ from modern thought in one major premise. Sixteenth-century authors do not suggest that women consider their personal desires to be as important as their husbands' or that they pursue a career instead of becoming wives and mothers. ${ }^{20}$ Their books do not present a platform for social reorganization, and their re-assessment of women's abilities resulted, at most, in changes in the private life of women: it improved public opinion of women, but effected no great change in their social role. ${ }^{21}$ Treatises like Capella's and Domenichi's argued that the old hierarchical relationship between men and women should be modifed, but the authors of these very treatises could not conceive of women in a truly equal role; writers on the family believed in the economic good sense and the morality of women, but began an idealization of the role of wife and mother that is only beginning to break down in our own day; and educators respected women's intelligence but gave them no field in which to apply it in their maturity. As a solution to the problems posed by thought about women, these authors offer an ideal woman who is man's equal in intelligence and morality but whose adherence to the traditional female virtues of chastity and obedience insures her acceptance of her continued inferiority in the sexual and social hierarchy.

Ariosto embodies the ideal of womanhood defined by the contemporary theorists in Bradamante, the imagined ancestor of the Estes and the heroine of the dynastic-encomiastic plot of the poem. By means of many of Bradamante's adventures, especially the "rocca di Tristano" (Canto XXXII), her visit to Merlin's cave (Canto III), and the complications preceding her marriage (Canto XLIV), as well as through the general role he assigns her, Ariosto firmly establishes the moral, physical, and intellectual equality of women as an essential premise of his poem, but, at the same time, he also demonstrates his belief in the value of the traditional hierarchical relationship between the sexes. 
Bradamante plays an extremely important role in the resolution of the dynastic plot of the Furioso. Like Lavinia in the Aeneid she is the destined mother of a great new line, but, unlike her epic ancestor, she loves her Aeneas and actively seeks him. ${ }^{21}$ Ariosto makes Bradamante's crucial role clear early in the poem in the episode in Merlin's cave (Canto III) in which she is given a knowledge of her destiny and descendants that is like Aeneas' Book VI of the Aeneid. This scene shifts a large part of the epic burden onto Bradamante's shoulders, but she does not thereby become a masculine figure. Her bearing throughout the adventure is appropriate to her sex as sixteenth-century writers defined it. She reacts to the news of her future importance with "rimesse e vergognose ciglia . . . tutta modesta," with humility, "di che merito son io, I ch'antiveggian profeti il venir mio?" (III. xiii), and with girlish delight "lieta de l'insolita aventura" (III. xiv). At the end of her interview with Merlin and Melissa, Bradamante is instructed in a method to save Ruggiero, who is Atlante's prisoner. Although these instructions correspond to Anchises' description of Aeneas' own immediate future of waging war, Bradamante is not a leader. Her duty is to find Ruggiero and marry him; her responsibility to the future will be fulfilled by her bearing of children.

Bradamante is moved and impressed by this display of her male offspring, but she is not entirely satisfied with her knowledge. She is curious about her female descendants, and in Canto Thirteen she asks Melissa, the magician, to tell her whether any of her female descendants "metter si può tra belle e virtuose." Melissa answers with a descriptive catalogue of Este daughters and wives, Isabella d'Este and her sister Beatrice, Ricciarda di Saluzzo, Eleonora d'Este, Lucrezia Borgia, and Renata of France, ladies whose virtue and accomplishments are praised frequently in the encomia of women written by Ariosto and his contemporaries.

In her eulogy Melissa establishes the importance of women in the history of the Este family but also distinguishes clearly between male and female roles. While men will excell at arms, women will be "madri... reparatrici e solide colonne di case illustri" and be noted for pietà, gran cor, gran prudenza, and continenza. The description of Isabella d'Este emphasizes that her appreciation of and encouragement of cortesia do not divert her from her primary duty: "sol perché casta visse / Penelope, non fu minor d'Ulisse." Lucrezia Borgia is handled in a similar fashion. Her beltà, virtù, and fama onesta make her outstanding, but her most special quality is her ability to instill in her children a sense of "costumi regi." As the moral instruction of their children is one of the major duties entrusted to women by Renaissance authors, 
this appreciation of Lucrezia's education of her children, like the praise of Isabella's chaste encouragement of courtly accomplishments, appeals specifically to a sixteenth-century sense of what a good woman ought to be. By means of the portraits of these Este ladies, Ariosto establishes as an accepted value within the poem the accomplished but domestic ideal developed by his contemporaries and firmly connects Bradamante with it. ${ }^{22}$

Many parts of the poem stress Bradamante's union of femininity with accomplishment; none does so more effectively than the adventure at the rocca di Tristano. This episode, added in the edition of 1532, makes it clear that Bradamante herself is equal to and yet different from men. Usually taken for one of Ariosto's most extreme pro-feminist statements, ${ }^{23}$ this passage stresses the differences between the sexes as forcefully as it attacks the restrictive definition of women. At the rocca di Tristano it is the custom

che 'I cavallier ch'abbia maggior possanza,

e la donna beltà, sempre ci alloggi;

e chi vinto riman, vòti la stanza,

dorma sul prato, o altrove scenda e poggi. (XXXII. xciv)

This custom is borrowed from Arthurian tradition with one allimportant change: no Arthurian romance includes the beauty contest between women. ${ }^{24}$ This added element brings the episode into the controversy about women because it makes it possible for Bradamante to win both contests and challenge the traditional distinctions between the sexes.

When Bradamante, who entered the castle because of her skill as a knight, is revealed to be a woman, the question is "se Bradamante abbia a considerarsi legittima ospite quale vincitrice in armi o in bellezza." ${ }^{25}$ Her host is for strict divisions between the sexes. He wishes to treat her as a woman and to expel Ullania, the woman who arrived before her. Bradamante makes many arguments in favor of her right to be considered a man. Claiming that no one can really know what she is without undressing her and that she must be a man since "di maschio è ogni mio gesto" (XXXII. ciii.6), Bradamante admits the thesis that she is a woman for the sake of argument only.

Poniamo ancor che, come a voi pur pare, io donna sia (che non però il concedo), ma che la mia beltà non fosse pare a quella di costei; non però credo che mi vorreste la mercé levare di mia virtù, se ben di viso io cedo. 
Perder per men beltà giusto non parmi quel c'ho acquistato per virtù con l'armi. (XXXII. civ)

Brand calls this entire speech "a fine legalistic argument, much of it, a reductio ad absurdum of the futile distinctions made between the sexes," 26 and indeed, Bradamante shows a cleverness with words that she has not demonstrated before. She proves quite clearly that she herself transcends any distinction between the sexes that the host could hope to make. She does not, however, prove that distinctions made between the sexes are futile or that all women can be judged by standards that usually apply to men. The poor "donna da l'isola perduta" stands as a reminder of the abilities of most women; she could not fight for her dinner. In this passage Bradamante has proven that women who are capable of equalling or surpassing men should be compared with men, she has not argued that all women can be compared with men. As Carrara says in his analysis of this passage, "a parità di prove parità di diritti." 27

Clever as Bradamante's argument is she ends with a physical threat not a logical feint:

E s'alcuno di dir che non sia buono

e dritto il mio giudizio sarà ardito,

sarò per sostenergli a suo piacere

che 'l mio sia vero, e falso il suo parere. (XXXII. cvi)

Talk as he may about Bradamante's womanhood, the host would have very little hope of enforcing his law against her. What really destroys the distinctions between the sexes in this passage is not what Bradamante says, but what she is capable of doing: in her body the traditional definition of woman breaks down. The narrator mentions the cleverness of Bradamante's arguments, but emphasizes the importance of her physical strength in carrying her point:

al signor de l'albergo persuade

con ragion molte e con parlare accorto,

ma molto più con quel ch'al fin concluse,

che resti cheto e accetti le sue scuse. (XXXII. cvii)

Bradamante's ability to force agreement is the final proof of her thesis that she would have the right to remain in the rocca even if she could not win the beauty contest.

At the same time that this episode mocks the traditional division between the sexes with its display of Bradamante's martial 
prowess, it paradoxically emphasizes her feminine beauty. The scene gains a great deal of its charm from the fact that Bradamante is in fact a lovely young woman. Ariosto insists on her beauty over and over, as when her hair tumbles out of its snood and the host discovers that she is not a man:

La donna, cominciando a disarmarsi, s'avea lo scudo e dipoi l'elmo tratto; quando una cuffia d'oro, in che celarsi soleano i capei lunghi e star di piatto, uscí con l'elmo; onde caderon sparsi giù per le spalle, e la scopriro a un tratto e la feron conoscer per donzella, non men che fiera in arme, in viso bella. (XXXII. lxxix)

Although we are already in on the secret and know that this knight is a woman, Ariosto succeeds in using our knowledge to create anticipation: we hear of the "cuffia d'oro" in line three and anxiously await the inevitable cascade of hair which Ariosto delays until lines seven and eight. By presenting the revelation of Bradamante's womanhood in stages Ariosto makes us rediscover what we know; he associates us with the physical point of view of the knight of the rocca and makes us participate in the startling discovery of her sex and sexual attractiveness.

Bradamante's attitude toward her sex in this episode invites comparison with Marfisa's in the land of the donne omicide, where Marfisa refuses to acknowledge that she does differ from men in one essential point. In her speech proclaiming her sword the equal of any man's weapon in all combats, Marfisa makes her competition with men explicit:
Ella dicea: - Prima v'ho a por la vita, che v'abbiate a por voi la libertade:
ma questa spada - e lor la spada addita, che cinta avea - vi do per securtade ch'io vi sciorrò tutti gl'intrichi al modo che $\mathrm{fe}^{\prime}$ Alessandro il gordiano nodo. - (XIX. lxxiv)

Ariosto emphasizes the foolishness of Marfisa's self-confidence here by making her indicate the sword at her side, "e lor la spada addita, che cinta avea." We laugh at Marfisa because she is proposing her sword as an able competitor in the one combat in which it cannot compete. Bradamante nowhere gives this sense that her self-image depends on ignoring her sexual difference from men. Her speech at the rocca reminds us of her sex, even as it denies it. Bradamante's "ma chi dirà, se tutta non mi spoglio, / 
s'io sono o s'io non son quel ch'è costei" (XXXII. cii.5-6) leads us to remember what Marfisa sought to forget. Bradamante does not want to prove herself in competition with men for the sake of general principles of equality, and she does not deny her womanhood out of reluctance to behave as a woman when such behavior is appropriate. Aware that she would rightfully win any beauty contest, she argues for her right to be judged as a man out of charity for Ullania "per pietà non vuol che se ne vada" (XXXII. ci.4).

In this episode Ariosto suggests an alternative to the old ideal of helpless beauty, represented in this case by Ullania. He does not replace it, however, with its exact opposite, the virago, a woman like Marfisa whose bearing and sense of herself divide her from her sex. He instead portrays a complex woman who combines physical strength with femininity. The episode demonstrates that women should be judged according to what they can do rather than what society has always said they are, but it does not deny all differences between the sexes, and it says nothing practical about the position of the independent woman in society or about relations between the sexes. These topics are taken up in the final episodes of the courtship of Ruggiero and Bradamante.

Toward the end of the poem Bradamante finds herself in a dilemma. She and Ruggiero have declared their love to each other; her brother Rinaldo has formally betrothed them; Bradamante has returned home expecting to marry Ruggiero immediately. She discovers, however, that her parents have planned a marriage between her and the son of the Greek emperor and expect her to be delighted at the prospect. This is an oddly concrete problem to find treated in a poem which thus far has dealt with the less everyday side of the lives of its heroes. The concern with money and social position seems to bring the episode closer to the values that govern the novelle told to Rinaldo than to those that rule in the body of the poem. Critics have been unanimous in identifying this section of the poem as borghese and have lamented its lack of poetic inspiration. Interested as he is in popular social forces at work in the poem, Piromalli can see little value in the "dramma economico borghese" and asserts that in this section "le prime crepe del Rinascimento cominciano ad apparire e anche artisticamente si avverte una stanchezza e una decadenza nel canto dell'amore contrastato dalla morale e dalle ambizioni dei genitori: il fuoco della fantasia non ha toccato le ultime vicende di Ruggiero e Bradamante." 28 Momigliano calls Canto Forty-four "uno dei peggiori del Furioso." He believes that the parental opposition to Bradamante's marriage offered Ariosto an opportunity to avoid 
the tired petrarchism which he sees as a flaw in almost the entire treatment of the love of Bradamante and Ruggiero, but that "il motivo rimane smorto. ${ }^{29}$ In other words, Ariosto has not succeeded in turning his middle class subject into poetry.

Certainly Piromalli's and Momigliano's sense that this last section of the poem is borghese is accurate, but their demand that Ariosto should have raised this material above its origins and infused it with high beauty or fantasia and a universal quality is inappropriate. The entire story of Bradamante and Ruggiero is borghese. The hero and heroine derive from romance and Boiardo to be sure, but the plot which Ariosto devised for them in his poem is derived from the Aeneid and serves the material purpose of celebrating the family of Ariosto's patron, a family recently enough risen to appreciate a dynastic epic.

Throughout the poem Bradamante has the aim of getting married and raising a family; to criticize her for this is to disregard her entire role in the poem. Momigliano complains that when Ariosto came to write the end of his story of Bradamante "si erano esauriti il candore, l'abbandono e la simpatia che sono la fonte ispiratrice di tutte le sue eroine sfortunate." It is true that in this scene and, indeed, until nearly the last stanzas of the poem Ariosto treats Bradamante with delicate humor and affection rather than with the "abbandono" that Momigliano desires, but it is also true that Bradamante is not one of the "eroine sfortunate." Her position in the poem is unique. All the other romantic heroines are helpless and only able to achieve their desires through clever manipulation of men (Angelica and Isabella) or dependence on men (Olimpia and Ginevra); as a result, the poet's protective sympathy at their distress (Angelica excepted, of course) is appropriate. Bradamante is a new kind of heroine; as we saw at the rocca, she manages to be feminine while being self-sufficient and the narrator does not attempt to arouse pity for her even in a scene where she is threatened with separation from the man she loves.

Of all the love stories in the Furioso the story of Bradamante and Ruggiero is tied the most specifically to Renaissance concerns. We have already seen that Bradamante is repeatedly set in a sixteenth century context; she is the legendary ancestor of ladies of Ariosto's own time, yet in herself has already achieved the ideal of womanhood which will be admired in Ariosto's society. The efficacy of this ideal is at stake in the final cantos of the poem. She is confronted with the dilemma of how to behave obediently and still marry Ruggiero, the man of her love and her destiny.

Faced with a conflict between her own desires and her parents' will, Bradamante recognizes that she ought to be obedient, "so 
quanto, ahi lassa! debbo far, so quanto / di buono figlia al debito conviensi" (XLIV. xliii.1-2). Bradamante's sense of the propriety of filial obedience has drawn criticism from those, like Rajna and Tomalin, mentioned above, who believe that her independent status as a knight should give her courage to defy her parents' wishes. To think of Bradamante as entirely independent is to misapprehend Ariosto's characterization of her: she is always portrayed as an accomplished woman with domestic goals. Unlike Marfisa, Bradamante is a woman first and then a knight, and, as we have seen, according to the most sophisticated sixteenth century thinkers, she can only remain a good woman if she is obedient.

The way in which Ariosto resolves the dilemma he has created for his character is consistent with the ideal of womanhood he establishes in the catalogue of Este ladies. Bradamante cleverly discovers that she owes obedience not only to her parents but to her brother:

S'io non sarò al mio padre ubbidiente, né alla mia madre, io sarò al mio fratello, che molto e molto è piú di lor prudente, né gli ha la troppa età tolto il cervello. (XLIV. xlvi. 1-4)

This speech is comic, certainly, but the comedy does not work against Rinaldo's authority; it makes the heroine look a bit silly and juvenile. Bradamante's trick of choosing to obey her brother is very revealing of her thoughts about herself. She does not consider going directly to Charlemagne. Instead, she finds a way to maintain the form of a traditional woman's behavior by appealing to the authority of a male member of her family. She, thus, conducts herself correctly according to the thought of Ariosto's time and the ideal the poet has created.

Only after her clever transfer of power over herself to her brother is Bradamante free to act to bring about the marriage. She does this by reminding Charlemagne that he is in her debt because of her military actions and then asking him a boon: that he not let her be given a husband who cannot beat her at arms. Bradamante's skill at arms is the quality that makes her unusual, accomplished. Here, she wants to use her accustomed independence to put herself under the authority of a husband. She knows that only Ruggiero can beat her; her cleverness is finally the quality that wins her what she wants; she has found a way to have her own desire and yet stay within the limits of obedience. The fact that Bradamante's plan does not work smoothly and nearly loses 
Ruggiero for her does not take away from the dignity and cleverness of her action, but it does re-inforce Ruggiero's superiority to her; she would not have fought her best had she known Ruggiero was her opponent. Because she believes she is fighting Leone, Bradamante really does not want to be beaten; she fights as well as ever she has, and her loss to Ruggiero in disguise proves that his ability in arms really is superior to hers.

In the Historia di Bradiamonte, the popular poem from which Ariosto probably took the device of Bradamante's requirement that the man she married be able to best her in battle, the element of willing submission is entirely absent. ${ }^{30}$ Bradiamonte's requirement is a device to prevent marriage completely, not just to accomplish it with the right person, and it is introduced in the stanza in which she enters the poem: "Bradiamonte mai nel mondo non volse marito, se non chi l'abatteva sopra il sito." ${ }^{\prime 31}$ Here, the rule is an established part of Bradiamonte's character, not a sudden inspiration of a clever way out of an emotionally difficult situation. Bradiamonte is not and never will be in love. When she is challenged by a prospective suitor, Amansor, the king of Barbary, she wins easily and her victory in single combat results in a victory over his retinue by the Carolingian army. Ariosto's reworking of this topic turns the rough Bradiamonte into a sixteenth-century lady. Bradamante is accomplished, yet uses her accomplishments to further her marriage, not to avoid it; she could be independent, yet she loves and is willing to relinquish her career when she marries and to assume a protected and obedient role.

It is clear that Bradamante sees marriage as a transfer of authority over herself. When she is separated from Ruggiero and afraid that he thinks she will marry Leone, she assures him that he is the only one she loves in terms that emphasize her freely given obedience:

A voi, Ruggier, tutto il dominio ho dato

di me, che forse è piú ch'altri non crede.

So ben ch'a nuovo principe giurato

non fu di questa mai la maggior fede.

So che né al mondo il piú sicuro stato

di questo, re né imperator possiede.

Non vi bisogna far fossa né torre,

per dubbio ch'altri a voi lo venga a tòrre. (XLIV. lxiii)

In the mouth of a woman of Bradamante's ability these are not mere metaphors. Without deprecating her own value, she speaks of her complete acceptance of Ruggiero's dominion over her. 
The last scene of the poem shows Bradamante acting as a wife for the first time. Before Ruggiero's final battle with Rodomonte, the narrator surveys the crowd of spectators noting briefly the anxiety of the ladies, the commoners, and the knights. His gaze settles on Bradamante, who also is worried despite her certainty that Ruggiero is stronger, braver and more honorable than Rodomonte; she wishes that she could protect Ruggiero by taking his place:

Oh quanto volentier sopra sé tolta l'impresa avria di quella pugna incerta, ancor che rimaner di vita sciolta per quella fosse stata piú che certa! Avria eletto a morir piú d'una volta, se può piú d'una morte esser sofferta, piú tosto che patir che 'l suo consorte si ponesse a pericol de la morte.

Ma non sa ritrovar priego che vaglia, perché Ruggiero a lei l'impresa lassi.

A riguardare adunque la battaglia

con mesto viso e cor trepido stassi. (XLVI. cxiv-v.1-4)

These lines show Bradamante in the moment of transition from her old role of warrior and protector of the, at times, ineffectual Ruggiero to her new role of wife obedient to and in need of protection by her husband. At the same time that Bradamante wishes she could stand in for Ruggiero in the duel, she recognizes that her chances of success are nothing compared with his, and the military superiority he established in his duel with her is confirmed. She is thinking here like a noble lady about to watch her lover fight a duel; her offer to fight in Ruggiero's place is animated by a spirit of loving self-sacrifice rather than by a sense of her own martial abilities. Ruggiero's rejection of Bradamante's offer confirms his dominion over her. She approaches him from the position of an inferior begging a favor, "non sa ritrovar priego che vaglia"; he has the authority to reject her plea and to expect her obedience.

In our last glimpse of Bradamante in the poem, she has lost all traces of her military character and is animated solely by love.

Non fu in terra sí tosto, che risorse, via piú che d'ira, di vergogna pieno; però che a Bradamante gli occhi torse, e turbar vide il bel viso sereno.

Ella al cader di lui rimase in forse, 
e fu la vita sua per venir meno.

Ruggiero ad emendar presto quell'onta,

stringe la spada, e col pagan s'affronta. (XL. cxxv)

This could be a description of Fiordiligi or Isabella, so beautiful, so inspirational, so passive has Bradamante become.

It is tempting to feel disappointment in Bradamante's withdrawal from action, but to do so is to misapprehend the quality of her excellence and ambition. Bradamante's inaction in these final scenes is justified by Ariosto's presentation of her throughout the poem. As we have seen, he consistently considers her talent subordinate to her goal and her attitude toward womanhood is reinforced by rhetorical praise of women whose primary virtues are chastity, piety, and dedication to family. Because her desire always was to marry Ruggiero and her military exploits were incidental to her domestic goal, Bradamante's submission to her husband is not a humiliation. Like the ideal lady of the controversy about women, she freely chooses not to be independent.

Yale University

\section{NOTES}

1 Augusto Turati, "Ruggiero e Bradamante," in L'Ottaza d'oro: La vita e opera di Ludovico Ariosto (Verona: Mondadori, 1933), p. 429.

2 Pio Rajna, Le Fonti dell'Orlando Furioso, 2nd ed. (Firenze: Sansoni, 1900), p. 54.

3 Margaret Tomalin, "Bradamante e Marfisa," Modern Language Review, 71 (1976), 540.

4 Mario Santoro, "Rinaldo ebbe il consenso universale," in Letture ariostesche (Napoli: Liguori, 1973), pp. 83-133.

5 Robert Durling, The Figure of the Poet in Renaissance Epic (Cambridge, Mass.: Harvard University Press, 1965), pp. 151-52.

6 Saint Thomas Aquinas, Summa Theologica, trans. Fathers of the English Dominican Province (New York: Benziger Bros., 1947), Question 92, Article 1 and Question 163, Article 4.

7 Ian Maclean in his The Renaissance Notion of Women (Cambridge: Cambridge University Press, 1980) gives detailed accounts of medical, legal and theological thought about women in the Renaissance.

8 See Leon Battista Alberti, I Libri della famiglia, ed. Ruggiero Romano and Alberto Tenenti (Torino: Einaudi, 1972), especially p. 264; Francesco Barbaro, De Re Uxoria with trans. by Alberto Lollio, in La letteratura italiana. Storia e testi, Vol. 13 (Milano - Napoli: Signorelli, 1952); Bernardino da Siena, Pagine devote sull'amor coniugale, ed. Gerolamo Lazzeri (Milano: Modernissima, 1924); and Giovanni Pontano, Trattato dell'obedienza, trans. M. Iacopo Baroncelli (Venezia: Giolito, 1568), Book III.

9 Lionardo Bruni d'Arezzo, "De Studiis et Literis," in Vittorino da Feltre and Other Humanist Educators, ed. and trans. William Harrison Woodward (1897; rpt. New York: Teacher's College, 1963), pp. 10-11.

10 See Juan Luis Vives' plan of instruction for Mary Tudor in Vives and the Renaissance Education of Women, ed. Foster Watson (New York: Longmans, 1912). 
11 See for example, the biographies presented by the Florentine Vespasiano da Bistici in his Libro delle lode e commendazione della donna in his Vite di uomini illustri del secolo XV, ed. L. Frati (Bologna, 1892).

12 Giovanni Sabadino degli Arienti, Gynevera de le clare donne, ed. Corrado Ricci and A. Bacchi della Lega, Scelta di curiosità letterarie, 223 (1887; rpt. Bologna: Forni, 1968), p. 38.

13 Giovanni Boccaccio, De Mulieribus Claris, ed. V. Zaccaria, Tutte le opere di Giozanni Boccaccio, Vol. X (Verona: Mondadori, 1970), pp. 134, 236.

14 As Guido Ghinassi has shown, the Cortegiano began as a treatise in defense of women and was expanded to its present form; see his "Fasi dell' elaborazione del Cortegiano," Studi di filologia italiana 25 (1967), p. 190.

15 Galeozzo Flavio Capella, Della Eccelenza et dignità delle donne (Venezia, 1526), ff. $26^{\mathrm{v}}-27^{\mathrm{T}}$.

16 Lodovico Domenichi, La Nobiltà delle donne (Venezia: Giolito, 1549), f. $1^{v}$.

17 La defensione delle donne d'autore anonimo: scrittura inedita del secolo XV ed. Zambrini, Scelta di curiosità letterarie, 148 (Bologna: Ramagnoli, 1870), p. 50, and Alessandro Piccolomini, Oratione in lode delle donne (Venezia: Giolito, 1549), ff. $31^{\mathrm{r}}$ and ${ }^{\mathrm{v}}$. Piccolomini's speech, delivered to the Accademia degli Intronati in Siena, opens with a comic critique of his own motives and such extreme claims for women's superiority that it seems a satire of the genre of defenses of women. After the introduction, however, it settles into a serious analysis of the oppression of women, the sources of anti-feminism, and the strong points in women's character. The mixture of self-conscious exaggeration and serious argument occurs frequently in defenses of women.

18 Baldesar Castiglione, Il cortegiano, ed. Bruno Maier (Torino: UTET, 1964), pp. 391-92.

19 Capella, f. 12.

20 Most sixteenth-century writers do not perceive a discrepancy between women's abilities and the role assigned them in society; those that do resolve the difficulty by asserting that women themselves find happiness in a subservient position. This argument is made very clearly in Sperone Speroni's "Dialogo della dignità delle donne" (Venezia, 1543), a debate on the necessity for wifely obedience. Beatrice d'Este sustains the inferiority of women; she speaks for most Renaissance theorists on female psychology when she explains:

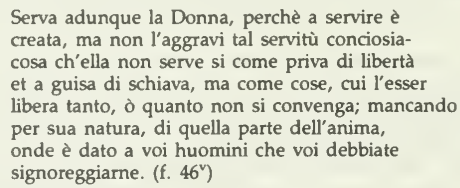

Beatrice's pro-feminist male companions fail to make any convincing arguments in favor of liberty for women; therefore, her arguments ought to persuade us that women are inferior. But Speroni creates a dilemma with Beatrice's display of her intellectual abilities; she is obviously any man's equal as her companions point out, and, thus, we feel she ought to be free of the bonds of obedience. Speroni solves this problem by presenting her acceptance of her position as heroic; her gracious playing of her role is the ultimate example of female virtue in her. For a very interesting discussion of the problems faced by educated women, see Margaret Leah King, "Thwarted Ambitions: Six Learned Women of the Renaissance," Soundings, 59 (1976), 280-304.

21 See Ezio Levi, "L'Orlando furioso come epopea nuziale," Archivium Romanicum, 17, No. 4 (1933), 459-96.

22 The domestic ideal is even present in the eulogy of accomplished women that opens canto thirty-seven. There Ariosto cites Vittoria Colonna as the primary contemporary embodiment of the feminine ideal. He presents her as an accom- 
plished woman who avoids any conflicts between active and domestic life by celebrating her husband in her work.

23 See Brand's opinion below.

24 Rajna, p. 502.

25 Enrico Carrara, "Marganorre," Annali della Scuola Normale Superiore di Pisa, 2, IX (1940), p. 9.

26 C.P. Brand, Ariosto (Edinburgh: Edinburgh University Press, 1974), p. 120.

27 Carrara, p. 9.

28 Antonio Piromalli, Motivi e forme della poesia di Ludovico Ariosto (MessinaFirenze: D'Anna, 1954), p. 117.

29 Attilio Momigliano, Saggio su l'Orlando furioso (Bari: Laterza, 1928), pp. 139, 140, 142 (quoted below).

30 See Rajna pp. 49-51 on Galiziella in the Aspramonte and pp. 593-7 for other examples of warrior ladies determined to marry only men able to vanquish them.

31 Historia di Bradiamonte, sorella di Rinaldo, ed. Giorgio Barini, in Cantari cavallereschi dei secoli XV e XVI (Bologna: Romagnoli, 1905), p. 162. 